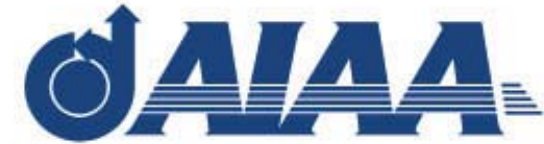

The World's Forum for Aerospace Leodership

\section{NASA Space Rocket Logistics Challenges}

Chris Bramon, Presenter; James R. Neeley, James V. Jones, Dr. Michael D. Watson, Sharon K. Inman, Loraine Tuttle; NASA Marshall Space Plight Center/EO and Kennedy Space Center/GP

SpaceOps2014, May 5-9, 2014, Pasadena, California, USA 


\section{Abstract}

- The Space Launch System (SLS) is the new NASA heavy lift launch vehicle in development and is scheduled for its first mission in 2017.

- SLS has many of the same logistics challenges as any other large scale program. However, SLS also faces unique challenges.

- This presentation will address the SLS challenges, along with the analysis and decisions to mitigate the threats posed by each. 


\section{OAIAA}

\section{Design Architecture}

\section{SLS Architecture Reference Configuration}

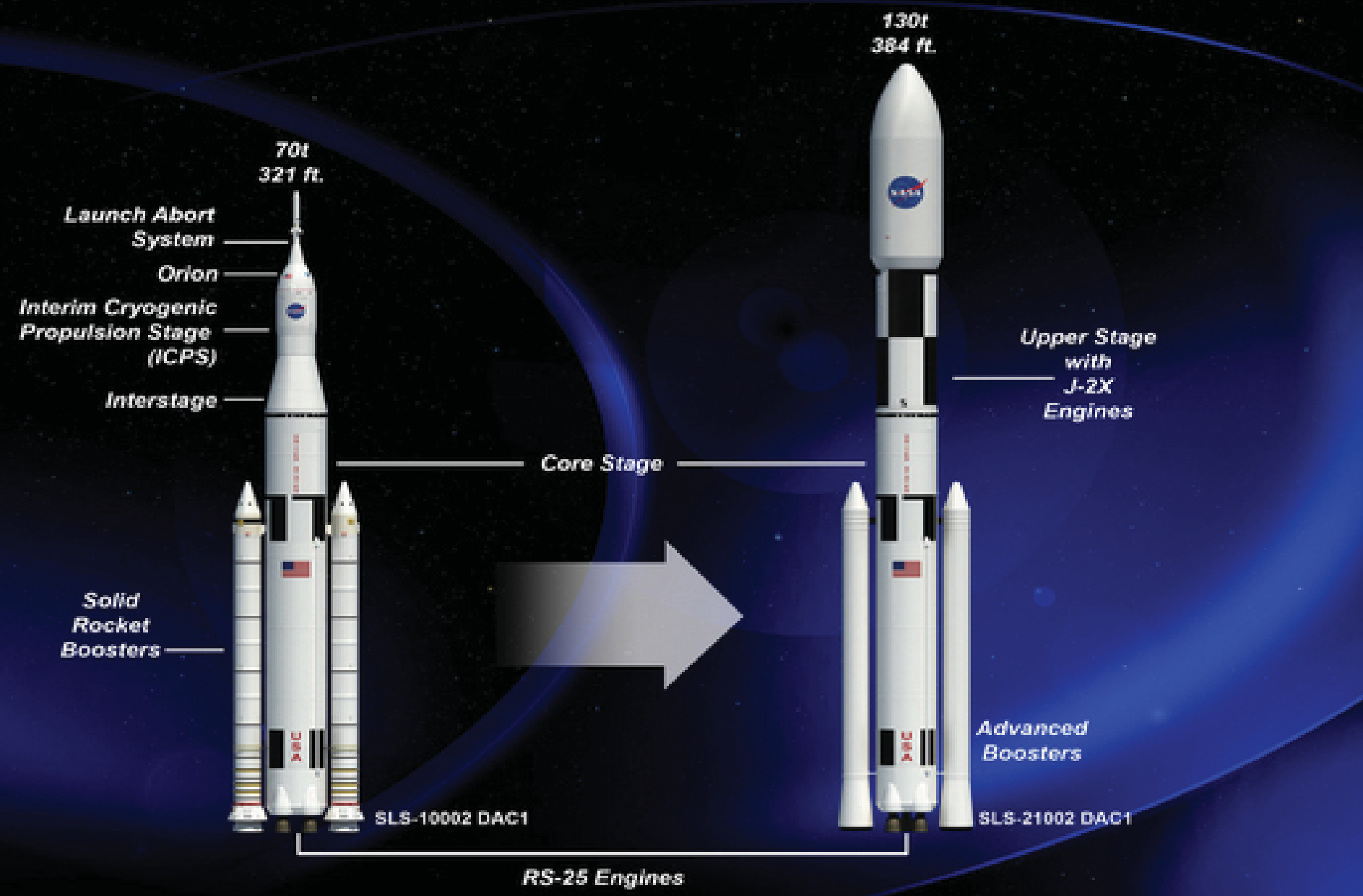




\section{OAIAa

\section{Traditional Approach for "Logistics"}

- Concepts and processes of Integrated Logistics Support (ILS) provide a significant opportunity to minimize life cycle cost of ownership of a system.

- Traditional application of ILS during the design, development, test and evaluation (DDT\&E) of a system typically consists of two different, but highly related processes:

- Designing a supportable system.

- Developing a reasonable, responsive and cost effective support solution. 


\section{OAIAA}

The World's Forum for Aerospoce Leodership

\section{ILS During System Development}

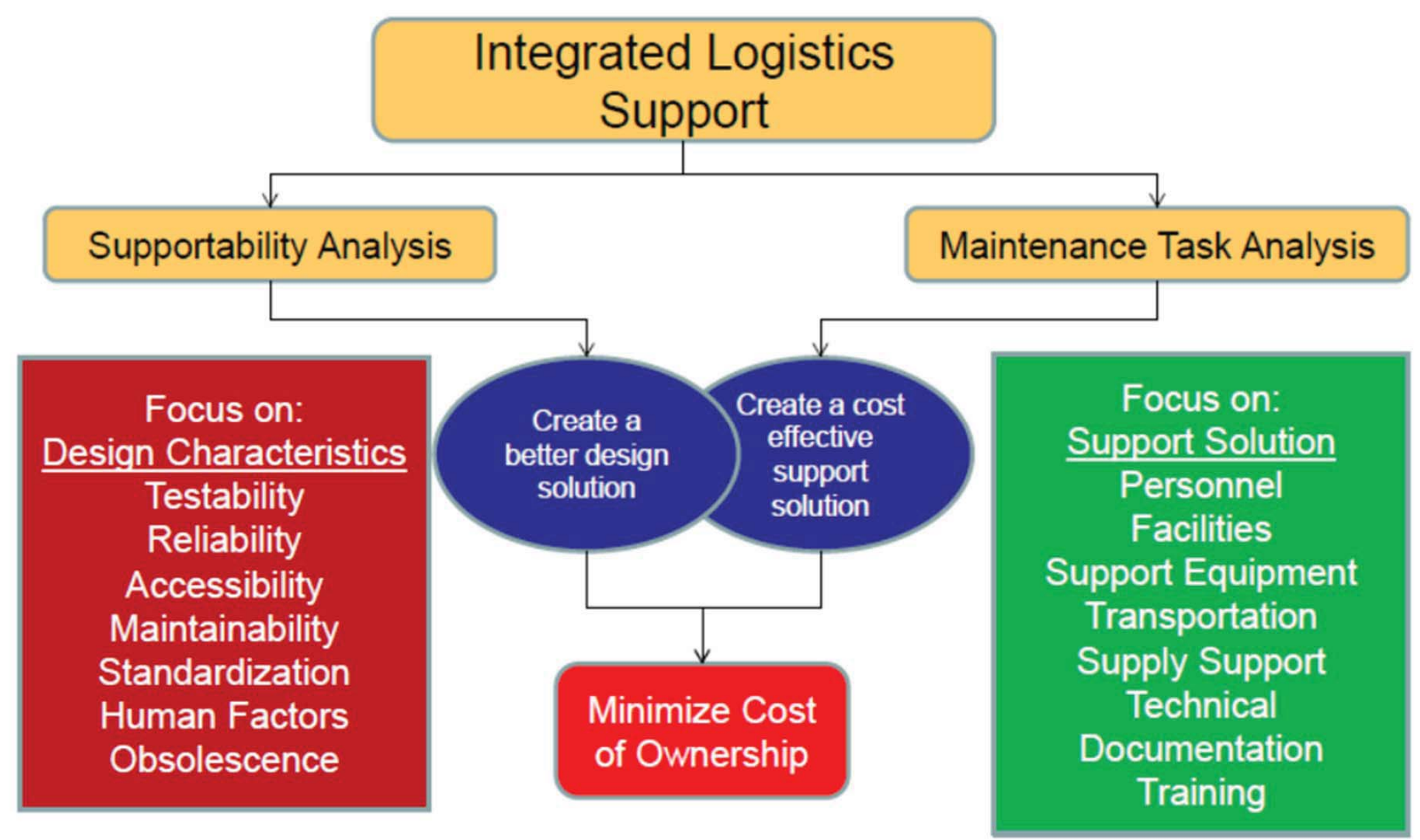




\section{Tailoring ILS}

- A simple comparison of traditional ILS concepts and processes with the unique circumstances of the SLS Program (SLSP) indicates that application of ILS must be drastically different to be effective.

- SLSP is performing a comprehensive, but nontraditional ILS program that will contribute to the program goals.

- Specific details of SLS challenges and ILS tailoring are addressed in the remaining charts 


\section{OAIAA}

The World's Forum for Aerospoce Leodership

\section{Supply Chain Impacts Due to Multiple Projects, Contractors,} and Vendors

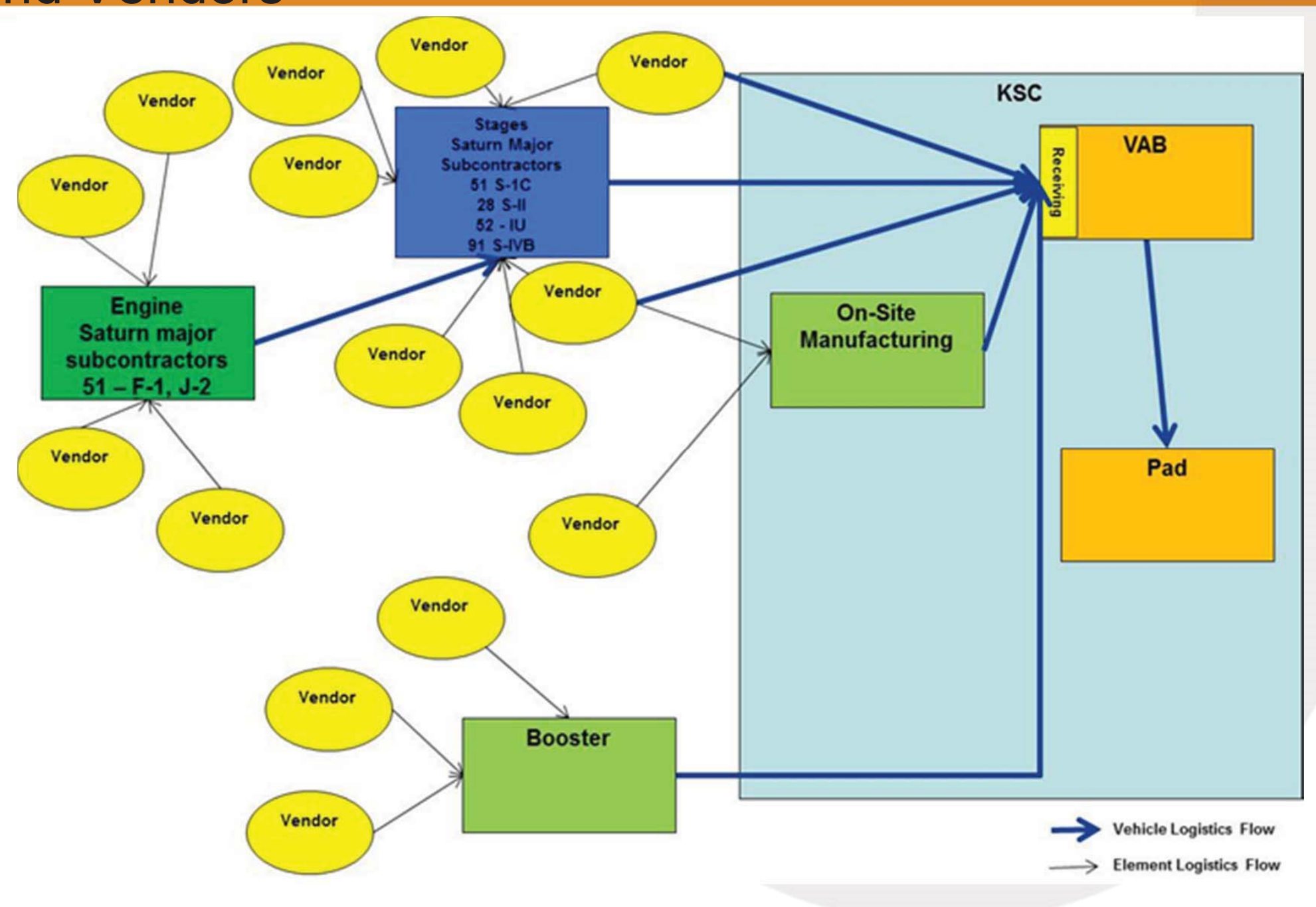




\section{NASA SLS Common Challenges and Threats}

\begin{tabular}{|l|l|}
\hline Challenge & Threat \\
\hline $\begin{array}{l}\text { Integration of multiple } \\
\text { geographically separated } \\
\text { programs }\end{array}$ & $\begin{array}{l}\text { Stakeholder communication, } \\
\text { conflicting schedules, lack of } \\
\text { commonality, gaps in } \\
\text { requirements and funding }\end{array}$ \\
\hline $\begin{array}{l}\text { Integration of multiple } \\
\text { geographically separated projects } \\
\text { within a program and multiple } \\
\text { contactors }\end{array}$ & $\begin{array}{l}\text { Stakeholder communication, } \\
\text { conflicting \& complex schedules, } \\
\text { lack of commonality, gaps in } \\
\text { requirements, different goals, lack } \\
\text { of flowed down requirements }\end{array}$ \\
\hline Funding constraints & Increased risk \\
\hline
\end{tabular}




\section{NASA SLS Unique Challenges and Threats}

\begin{tabular}{|l|l|}
\hline Challenge & Threat \\
\hline $\begin{array}{l}\text { Low manifest rates and } \\
\text { frequencies (Up to four years } \\
\text { apart) }\end{array}$ & $\begin{array}{l}\text { Costly logistics solutions, } \\
\text { increased risk for availability of } \\
\text { skilled personnel resources }\end{array}$ \\
\hline $\begin{array}{l}\text { Architecture Block upgrade } \\
\text { approach }\end{array}$ & $\begin{array}{l}\text { Delay for operational phase, } \\
\text { increased cost for changing } \\
\text { support solutions: LSA, } \\
\text { resources, sparing philosophy }\end{array}$ \\
\hline $\begin{array}{l}\text { Mixed new and heritage } \\
\text { hardware }\end{array}$ & $\begin{array}{l}\text { Obsolescence, parts marking, } \\
\text { commonality }\end{array}$ \\
\hline $\begin{array}{l}\text { Multiple projects (elements) } \\
\text { with individual milestone } \\
\text { reviews }\end{array}$ & $\begin{array}{l}\text { Limited personnel resources, } \\
\text { design interface issues }\end{array}$ \\
\hline $\begin{array}{l}\text { Dictated flat funding } \\
\text { constraints, no inflation allowed }\end{array}$ & $\begin{array}{l}\text { Increased risk for adequate } \\
\text { logistics support }\end{array}$ \\
\hline
\end{tabular}




\section{NASA SLS Common Threats and Analysis}

\begin{tabular}{|l|l|}
\hline Threat & Analysis/Activities \\
\hline $\begin{array}{l}\text { Multiple Programs: Stakeholder } \\
\text { communication, conflicting } \\
\text { schedules, lack of commonality, } \\
\text { gaps in funding. }\end{array}$ & $\begin{array}{l}\text { Cross-Program Logistics Integration } \\
\text { Team (LIT) established to provide } \\
\text { communication and work } \\
\text { concerns/issues }\end{array}$ \\
\hline $\begin{array}{l}\text { Multiple Projects: Stakeholder } \\
\text { communication, conflicting } \\
\text { schedules, lack of commonality. }\end{array}$ & $\begin{array}{l}\text { SLSP ILS Team established for } \\
\text { integration of Elements' schedules, } \\
\text { data, and analysis. }\end{array}$ \\
\hline $\begin{array}{l}\text { Multiple prime contractors: Different } \\
\text { goals, lack of flowed down } \\
\text { requirements. }\end{array}$ & $\begin{array}{l}\text { Contractors included in SLSP ILS Team } \\
\text { activities, tailored Data Requirements } \\
\text { Descriptions (DRDs) implemented. }\end{array}$ \\
\hline Schedules: Conflicts, complexity. & $\begin{array}{l}\text { SLS Integrated Master Schedule (IMS) } \\
\text { established with inter-relationships. } \\
\text { Logistics Support Date (LSD) concept } \\
\text { implemented. }\end{array}$ \\
\hline Funding: Increased risk. & $\begin{array}{l}\text { Implemented engineering bottoms-up } \\
\text { life cycle cost (LCC) and identified } \\
\text { program risks for mitigation. }\end{array}$ \\
\hline
\end{tabular}




\section{NASA SLS Unique Threats and Analysis}

\begin{tabular}{|l|l|}
\hline Threat & Analysis/Activities \\
\hline $\begin{array}{l}\text { Low manifest rates: Costly logistics } \\
\text { solutions, increased risk for } \\
\text { availability of skilled personnel } \\
\text { resources. }\end{array}$ & $\begin{array}{l}\text { Minimal approach for first two flights } \\
(2017 \text { \& 2021). Phased approach for } \\
30 \text {-year life cycle integrated logistics. }\end{array}$ \\
\hline $\begin{array}{l}\text { Block upgrade approach: Delay for } \\
\text { operational phase, increased cost } \\
\text { for changing support solutions: } \\
\text { LSA, resources, sparing philosophy. }\end{array}$ & Risk assessments. \\
\hline $\begin{array}{l}\text { Hardware: Obsolescence, parts } \\
\text { marking, commonality. }\end{array}$ & $\begin{array}{l}\text { Materials assessment, sustaining } \\
\text { engineering planning. }\end{array}$ \\
\hline $\begin{array}{l}\text { Milestone reviews: Individual project } \\
\text { element reviews, limited personnel } \\
\text { resources, design interface issues. }\end{array}$ & $\begin{array}{l}\text { Integrated reviews. Element } \\
\text { supportability reviews. }\end{array}$ \\
\hline $\begin{array}{l}\text { Funding: Increased risk for } \\
\text { adequate logistics support. }\end{array}$ & Identification of budget risks. \\
\hline
\end{tabular}


Element Analysis Types and Data

- SLS Program Data Requirements Description (DRD) for "Element Logistics Support Data":

- Maintenance Significant Items (MSI)

- Provisioning Requirements

- Long Lead Items, Interim Support Items

- Line Replaceable Units (LRUs)

- Maintenance Task Analysis (MTA)

- Level of Repair Analysis (LORA)

- Logistics Support Resources 


\section{OAIAA}

The World's Forum for Aerospoce Leadership

\section{Lessons Learned from Ares 1-X}

- Supply chain responsibilities not clear between contracts.

- Supply Support process issues.

- Material quantities uncertain, real time demands constant.

- No processes ready to transfer material between programs.

- Inventory management was resource intensive: multiple databases, no accountability identified for parts.

- Material distribution issues.

- Mystery shipments caused delays, processing received expedited shipments time-consuming and degraded intent.

- Receiving inspection issues, confusion over requirements. 


\section{OMAa \\ The World's Forum for Aerospoce Leodership}

\section{Applying Lessons Learned}

- Progress has been made to apply several Lessons Learned from Space Shuttle, Constellation Ares/Ares 1-X, and Space Station.

- Implemented NASA Agency "Program and Project Life-Cycle Logistics Support Policy", NASA Policy Directive (NPD) 7500.1C. Includes Supportability, ILS and LSA.

- Established an engineering bottoms-up Life Cycle Cost capability.

- Established a Program ILS Team that includes Elements, contractors, and collaboration with launch site.

- Cross-Program Logistics Integration Team (LIT) includes the three NASA Exploration Programs. 


\section{Applying Lessons Learned (continued)}

- Reliability, Availability, Maintainability, Supportability. Cost, and Testability considered.

- LRU remove and replace analysis.

- Collaboration on-going with launch site for streamlined shipping and receiving processes, common warehouse, and improved inventory management.

- Flight and ground hardware transfer points, processes, and procedures being addressed.

- Launch processing requirements for materials, fluids, etc., being worked, to include plans to fund the launch site to provide these items. 


\section{Applying Lessons Learned (continued)}

- Clarifying Supply Chain Management (SCM), subject matter expert study in-progress.

- Commonality (Standardization) included as evolving consideration for materials and parts.

- Supportability Engineering exists as a discipline of Systems Engineering and Integration (SE\&l) at Program level.

- Sustaining Engineering part of early planning.

- Maintenance planning and analysis included.

- Technical Performance Metrics (TPMs) include Launch Availability and Maintenance Down Time. 


\section{Initiatives}

- Established and implemented SLSP ILS Team, includes Elements and contractors.

- Performed Program supportability assessments of Elements' ILS and LSA plans and execution.

- Established PowerLOG-J as common LSA Record (LSAR) database with launch site.

- Modification of existing water barge for large item transport, avoidance of major new design effort. 


\section{Initiatives (continued)}

- Supportability applied to Ground Support Equipment (GSE) along with flight hardware.

- Proposed efforts to evolve current integrated vehicle fault management (IVFM) model capability to include isolation capability to ambiguity group of 4-5 LRUs.

- Logistics Support Date (LSD) approach that addresses readiness of support infrastructure. 


\section{Decisions - Drivers}

- Policy Drivers

- Maximize use of contractor Best Practices.

- Limited Program-imposed management and control plans.

- Architecture Block upgrade approach.

- SE\&I Program Oversight and Insight with Elements.

- Key target is initial launch in December, 2017.

- Risk-based approach to affordability. 


\section{Decisions (continued)}

\section{- Process tailoring}

- Ensure the vehicle support infrastructure is adequate, has everything we need....nothing we don't.

- Ensure the design is successful within cost constraints.

- Integrate ILS efforts across the Elements for support of vehicle assembly and integration activities.

- Perform Logistics Support Analysis (LSA) under systems engineering to integrate an economical support approach. 


\section{OPIAA \\ The World's Forum for Aerospoce Leadership}

\section{Decisions (continued) for SLS Supportability Implementation}

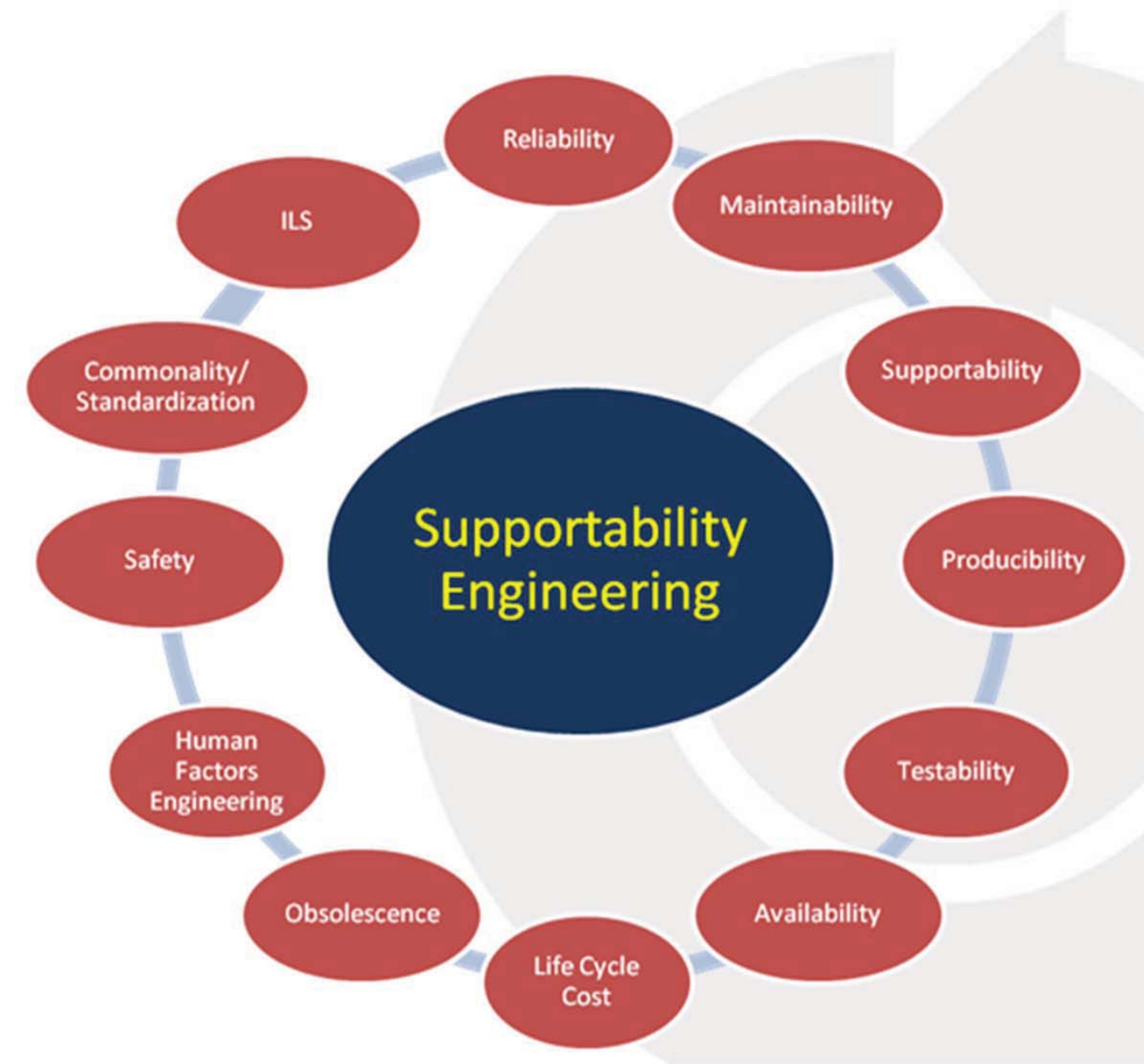


Decisions (continued)

- SLSP ILS Team Insight and Oversight

- Functional team within the SE\&I Operations Discipline Lead Engineering (ODLE) organization.

- Includes capability to perform integration analysis and collaboration with the SLS Elements and launch site

- SLSP LSD is April 15, 2017.

- Identify and mitigate risks for Block 1.

- Implement life-cycle logistics support. 


\section{Conclusion}

- SLSP is applying modified traditional and innovative concepts for supportability and logistics engineering.

- SLSP is applying lessons learned where possible.

- Path Forward:

Ensure hardware availability for the first two testoriented flights in 2017 and 2021 and work toward design-in-supportability and ILS for maturing designs for a thirty-year program. 


\section{ONINA}

The World's Forum for Aerospace Leadership 